\title{
ARE ISLAMIC BANKS SUFFERING FROM A MODEL MISFIT? A COMPARISON WITH COOPERATIVE BANKS
}

\author{
Rosana Gulzar ${ }^{1}$, Mansor H. Ibrahim ${ }^{2}$ and Mohamed Ariff ${ }^{3}$ \\ ${ }^{1}$ INCEIF, Singapore, rosanagulzar@gmail.com \\ ${ }^{2}$ INCEIF, Malaysia, mansorhi@inceif.org \\ ${ }^{3}$ INCEIF, Malaysia, ariff@inceif.org
}

\begin{abstract}
For the first time, this study investigates whether, in mimicking conventional banks, Islamic banks have become less stable than their theoretical equivalent: cooperative banks in Europe. Theoretically, the prohibition of interest should have pushed Islamic banks towards mutuality and profit-sharing, which have been argued as stabilising. In practice, however, banks are pushed for growth under a debt-driven commercial banking model, which is not only antithetical to the Shariah but is also destabilising. This may explain why empirical findings are still divergent in Islamic banking stability studies. Our study employs the generalised method of moments (GMM) system to compare the stability of 37 Islamic banks against 1,536 cooperative banks in Europe during the 2008 crisis and post-non-crisis years. Interestingly, we found consistent and significant evidence that Islamic banks are less stable than cooperative banks in both macroeconomic conditions. This has significant policy implications, the most important of which is to steer reform efforts away from refurbishing Islamic commercial banks and towards building an entirely new Islamic cooperative bank, based on the model in Europe.
\end{abstract}

Keywords: Islamic, Commercial, Cooperative, Banking, Stability. JEL Classification: G01; G21; G28.

Article history:

Received : : August 30, 2019

Revised : November 1, 2019

Accepted : April 3, 2020

Available online : May 20, 2020

https://doi.org/10.21098/jimf.v6i2.1086 


\section{INTRODUCTION}

\subsection{Background}

Financial stability has become critical in a crisis-plagued world. Since the 2008 financial crisis, regulatory reforms have largely been directed at commercial banks, which are known to exacerbate credit booms and go bust (Bank for International Settlements, 2010). Scholarly studies on Islamic banking, a growing segment within the commercial banking sector, are increasing but several issues remain. Firstly, the comparison within Islamic banking studies is with commercial banks, which does not seem to consider the dichotomy between Islamic banking theory and practice. While, theoretically, the interest prohibition is behind the drive towards mutuality and partnership in finance - which are argued to be stabilising - in practice, Islamic banks are trapped within the profit-maximising mode of commercial banks through fixed-rate products that resemble interestbased deposits and financing.

This paradox seems to have led to the second issue of divergent findings on Islamic banking stability. While some studies have located evidence of a stabilising effect, of late, there has been an increase in contrary findings in wellreputed journals. Some studies show no significant differences between Islamic and commercial banks. For the first time in stability studies, this paper argues that a more accurate comparison would be with cooperative banks, with whom Islamic banks share similar theoretical foundations. Both emphasise cooperation, solidarity, and social welfare.

Scholars such as Siddiqi (2006), Ariff (2014) and Mansour et al. (2015) note a widening dichotomy between Islamic banking theory and practice. In theory, Islamic banks are supposed to embody Shariah ideals such as mutuality, levels of participation, the sharing of profits and losses, and social welfare. These could have translated into the banks' structure regarding a mutual or benevolent ownership and business model that emphasises a well-rounded range of objectives, as well as profit seeking. In practice, however, there is significant evidence that, globally, Islamic banks are becoming assimilated with interest-based commercial banks (Azmat et al., 2015; Chong \& Liu, 2009; Khan, 2010). This is most likely the result of being pushed for growth under the commercial banking model. Being shareholder driven, both base their operations on sound business principles and profit maximisation. Social welfare comes lower in the list of priorities.

When the stability of Islamic banks was compared with their conventional peers, this may have led to conflicting empirical results. While a significant number concur with the notion that Islamic banks are more stable (Abedifar et al., 2013; Beck et al., 2013b; Ibrahim \& Rizvi, 2018), recently, an increasing number of works use advanced econometric techniques such as discrete-time duration modelling and market-based risk measures; this found evidence to the contrary (Abedifar et al., 2017; Alandejani et al., 2017; Kabir et al., 2015). There is concern that often, divergent results are within the studies themselves.

The lower stability of Islamic banks is likely because not only do they fervently mimic the debt-based model of commercial banks, which is, itself, destabilising, but Islamic banks are also hampered by Shariah constraints, which prevent a laissez-faire use of interest- or speculation-linked products such as repurchase agreements (repos) and derivatives. These benefit conventional banks. 


\subsection{Objective}

Taking the cue from scholars such as Siddiqi (2006), Chapra (1985) and El-Gamal (2006a and 2006b), who suggested mutuality in the ownership of Islamic banks, this study aims to close the gap between theory and practice in Islamic banking by investigating whether the mutual-based model of cooperative banks in Europe is a better fit for the Shariah values that should underpin Islamic banking. Most significantly, the literature on cooperative banking sheds light on how this model overcomes the problems of moral hazard and adverse selection brought by the steep information asymmetry of PLS contracts, thereby increasing stability.

In Europe, there is an increasing, although still a minority, view that the more diversified structure of its financial systems, including mutual institutions such as cooperative and savings banks, helped them recover from the crises better than other countries (Goglio \& Alexopoulus, 2014; Groeneveld, 2014a). The cooperative business model, which is different from commercial banking as explained in Table 1, has been theoretically argued to lend itself well to stability. Its mutual nature aligns the interests of various stakeholders from owners to depositors and borrowers. Conflicts of interest are, thus, minimised, although not eliminated.

Table 1.

Cooperative vs Commercial Banks

\begin{tabular}{|c|c|c|}
\hline Features & Cooperative & Commercial Bank \\
\hline Owned by & $\begin{array}{l}\text { Members who are also depositors and } \\
\text { borrowers }\end{array}$ & $\begin{array}{l}\text { Shareholders who are not directly } \\
\text { involved in the business }\end{array}$ \\
\hline Classification & Stakeholder banks & Shareholder banks \\
\hline Core business & Deposits and lending (D/L) & $\begin{array}{l}\text { While } \mathrm{D} / \mathrm{L} \text { is also core, large } \\
\text { commercial banks also sell risky } \\
\text { investment products such as } \\
\text { structured deposits }\end{array}$ \\
\hline Business goals & $\begin{array}{l}\text { - Dual-bottom line - financial and } \\
\text { social objectives } \\
\text { - Accumulate capital for } \\
\text { intergenerational endowment } \\
\text { - Provide services e.g. lending } \\
\text { which may be at below market } \\
\text { rates }\end{array}$ & $\begin{array}{l}\text { - Profit-maximisation is central to } \\
\text { the business model } \\
\text { - Increasing return on equity } \\
\text { and market capitalisation for } \\
\text { shareholders } \\
\text { - Provide products and services that } \\
\text { are profitable }\end{array}$ \\
\hline Business horizon & Long-term & Short-term \\
\hline Regulated by & $\begin{array}{l}\text { Members mainly, also central bank } \\
\text { and regulatory institutions such as } \\
\text { Basel }\end{array}$ & $\begin{array}{l}\text { Central bank and regulatory } \\
\text { institutions }\end{array}$ \\
\hline
\end{tabular}

Source: Author, TIAS School for Business and Society of Tilburg University. (2015). Governance of European Cooperative Banks: Overview, Issues and Recommendations.

Long-termism is also common among stakeholders, perhaps because in Europe, cooperative banks are like community banks in the way they nurture lifelong relationships with customers and align their business goals to society's economic endeavours. Cooperative banks are also known to keep to a conservative business model based on retail banking, which is likely forced on management by 
owners and customers. Commercial banks, however, are known for their shorttermism (Kay, 2016).

These features seem to have ensured their longevity, with many cooperative banks surviving since the mid-1800s. Coincidentally, they also embody more of the Shariah ideals of mutuality, partnership, and social well-being. Although cooperative banks charge interest, the founding objective has always been for the rates to be reasonable enough to enable those rejected by profit-driven commercial banks to receive financing. Their mutual nature, with a hint of benevolence, seems to have contributed to their stability.

This study, thus, seeks to determine, for the first time, whether Islamic banks are suffering from a business model misfit by comparing their stability against cooperative banks in Europe. The latter may be a more feasible implementation of the PLS-based model, which has been theoretically argued to lead to stability.

This study, thus, compares the stability of Islamic banks from five major Islamic finance countries with cooperative banks in Europe during the 2008 crisis and post-non-crisis years (2010-2015). The two periods serve as a test of their performance during a time of instability followed by relative stability. The years between 2010 to 2015 are interesting in the fact that the abnormal has become normal with an almost decade of protracted recovery characterised by lacklustre economic growth, tepid inflation, high unemployment, and stagnating wages (Solomon, 2014). It would, thus, be interesting to compare the stability of Islamic banks with that of cooperative banks during such a period.

This study contributes to the literature in three ways. Firstly, it advances the arguments of the few scholars who state that, theoretically, the Islamic banking model is closer to that of cooperative banks (Chapra, 1985; El-Gamal, 2006a, 2006b; Siddiqi, 2006). It does this by being the first to draw parallels between Islamic banks and cooperative banks in Europe, given their Shariah links.

Secondly, and more significantly, this study is the first to link this argument with the stability puzzle in Islamic banking. It notes that, theoretically, Islamic banks are argued to be more stable than their conventional peers due to features such as mutuality and profit-sharing. Empirically, however, the evidence is mixed.

Thirdly, in terms of technique, this study is among the few in both Islamic and cooperative banking stability studies to use a system generalised method of moments (GMM), an advanced econometric method. It is particularly advantageous in studies with endogeneity problems, including ours, given the inclusion of the lagged dependent variable, the Z-score, which is our stability indicator in the equation. This study, thus, pushes the frontier by employing an advanced econometric technique to solve a puzzle regarding the significant policy implications on the development of Islamic banking.

Interestingly, as per the hypothesis, we found that Islamic banks have been significantly and consistently less stable than cooperative banks in Europe during both the 2008 crisis and the non-crisis years that followed.

The rest of this study is structured as follows. Section Two reviews the literature while Section Three describes the empirical model and methodology. Section Four discusses the empirical results and Section Five concludes. 


\section{LITERATURE REVIEW}

\subsection{Background Theory}

Early Islamic economists such as Muhammad Umer Chapra (1985) and Nejatullah Siddiqi (1983a, 1985) agree on the socio-economic approach of Islamic finance, in which the exploitations of riba are eradicated through a PLS system; being more 'just' indicates that it is also more stable. According to these economists, the PLS model would be dynamically stable as variable returns on both sides of the balance sheets allow banks to pass all shock effects from their financing, for example, to customers via returns on investment deposits. The stabilising feature is, thus, inbuilt compared to conventional banks, which, due to fixed returns on their assets and liabilities, have had to rely on other stabilising mechanisms such as liquidity and capital buffers.

These same scholars took the concept of PLS further by enjoining cooperation and mutuality in the ownership of Islamic banks. They state that a mutual-based structure is a better fit for the Shariah goals of participation, prudence, longtermism and, therefore, banking stability. Recent thinkers such as El-Gamal (2006a, 2006b) argue that the mutual-based banking model is a more effective way of meeting the Shariah prohibitions of riba and gharar (uncertainty), which serve not only to ensure fairness in transactions but also prudential regulation and risk management. El-Gamal, however, does not discuss in sufficient depth the considerations for a mutual-based Islamic bank. Most recently, al-Muharrami and Hardy (2013) have noted the similarities between a cooperative bank and an ideal Islamic bank. They reckon that, although Islamic banking is consistent with mutual ownership, currently, the extent of mutuality, if any, is only in the products; however, in cooperative banking, the enjoined stakes go all the way back to the ownership structure.

In reality though, Islamic banks have taken the cue from a theoretical model developed by Baqir as-Sadr, an Iraqi scholar. Although he is in agreement with Islamic economists on the need for a PLS-based bank, as-Sadr is more accommodating, due to the omnipresence of conventional banking. Together with the ingenuity of Sami Homoud, an Islamic finance scholar, a conventional banker of 22 years, the way was paved for the legalistic approach, which allowed Islamic banks to replicate the debt-based model of their conventional counterparts.

Empirically, therefore, the stability of Islamic banks remains a contested issue (Table 2). While, in theory, the model is synonymous with profit sharing and mutuality, in reality, the practice increasingly mimics conventional banking, also reflecting its tendencies for profit-maximisation and desensitisation to social welfare (El-Gamal, 2006b; Gulzar, 2016; Hegazy, 2006; Kuran, 1995). While some studies found evidence of a stabilising effect, more recently, an increasing number of studies in well-reputed journals have findings to the contrary. 
Table 2.

Divergence of Results on Stability of Islamic versus Commercial Banks

\begin{tabular}{lll}
\hline More Stable & \multicolumn{1}{c}{ Less Stable } & \multicolumn{1}{c}{ No Significant Difference } \\
\hline Darrat (1988) & Hussain and Al-Ajmi (2012) & Abedifar et al. (2013) \\
Bashir et al. (1993) & Beck et al. (2013b) & Beck et al. (2013b) \\
Čihak and Hesse (2010) & Mobarek and Kalonov (2014) & Bourkhis and Nabi (2013) \\
Abedifar et al. (2013) & Kabir et al. (2015) & Kabir et al. (2015) \\
Beck et al. (2013b) & Ashraf et al. (2016) & \\
Farooq and Zaheer (2015) & Abedifar et al. (2017) & \\
Ibrahim (2016) & Alandejani et al. (2017) & \\
Pappas et al. (2017) & Alqahtani et al. (2017) & \\
Sorwar et al. (2016) & & \\
Ibrahim and Rizvi (2018) & & \\
\hline Source: Author compilation & &
\end{tabular}

Abedifar et al. (2013) for example, have almost 120 Islamic banks in their sample; these banks had lower credit risk than conventional banks during the period 19992009. More recently, Ibrahim (2016), in his study of 37 banks in Malaysia, found that the cyclicality of bank lending applies only to conventional banks. The 16 Islamic banks in the sample managed to continue extending financing despite the declines between 2001 and 2013. Sorwar et al. (2016) used estimates of the expected shortfall (ES), which incorporates losses beyond the Value-at-Risk (VaR) measure, and discovered that Islamic banks were less risky than conventional banks, especially during the 2008 crisis.

Recently, however, there have been an increasing number of findings to the contrary. Alandejani et al. (2017) employed a discrete-time duration model, a sophisticated econometric technique, and discovered that between 1995 and 2011, GCC-based Islamic banks survived for a shorter time period and had a higher incidence rate of failure than conventional banks. Ashraf et al. (2016) also discovered that, based on the random effect estimation method, GCC-based Islamic banks are less stable than their conventional counterparts.

The 2008 crisis prompted a slew of studies on banking stability. Recent ones by Mobarek and Kalonov (2014) and Alqahtani et al. (2017) questioned earlier claims that Islamic banks successfully rode out the crisis. Mobarek and Kalonov (2014) determined that their superior stability persisted only up to 2007. Thereafter, their mean Z-score seemed to decline drastically. Several studies by Beck et al. (2013b), Bourkhis and Nabi (2013) and Kabir et al. (2015) also found no significant differences in the stability of Islamic versus conventional banks during and outside of the 2008 global financial crisis (GFC).

Against these divergent findings, the storyline is more coherent for cooperative banks. Although largely ignored by policymakers and academia, there is overwhelming empirical evidence within the limited studies conducted for this type of bank that support the idea that they have superior stability.

Theoretically, academics such as Kalmi (2007) and Butzbach and von Mettenheim (2015a) explain the competitive advantages of cooperative banks over their commercial counterparts through different layers of the firm's theories, modern banking theory, and the new-age alternative banking theory. They argue that the mutual nature of cooperative banks aligns the interests of various 
stakeholders, thus reducing these conflicts of interest. Cooperative banks can lower the agency costs between a bank's stakeholders more effectively than a commercial bank. Because borrowers are also depositors and members in a cooperative bank, there are fewer chances of borrowers absconding with the money or taking unnecessary business risks. Furthermore, borrowers are severely restricted by relationship-based lending in cooperative banks and the peer pressure among members and in the local community (Ghatak, 2000; Valnek, 1999).

Butzbach and von Mettenheim (2015b) also argue that it is possible to sketch a new theory of alternative banking by building on unchartered developments within the modern banking theory, specifically the theory of inter-temporal risk smoothing. The concept refers to banks' ability to accumulate capital during good times and use it within the hard times, thereby granting them a comparative advantage (Allen \& Gale, 1997; Ayadi et al., 2010). Cooperative banks are suited to this function because they can quickly accumulate deposits during hard times based on the trust earned through a long history of serving low-income households in the community and banks' stable governance, social mandates, and prudent behaviour. This then allows cooperative banks to favourably adjust their lending rates to customers, thereby smoothing the inter-temporal risk (Altunbas et al., 2001; Ayadi et al., 2010; Groeneveld, 2014b).

These narratives are supported in the limited empirical studies conducted on cooperative banks (Table 3). Chiaramonte et al. (2013), in their analysis of over 15,000 banks, which include commercial, cooperative and savings banks from 26 OECD countries between 2001 and 2010, found that a significant market share of cooperatives helped to stabilise financial systems during the 2008 crisis although the role was reduced during periods of stability. Hesse and Čihák (2007) also discovered, through their analysis of the z-scores of a similar sample of over 15,000 banks during the period 1994-2004, that cooperative banks are more stable than commercial banks. This is evident through their lower volatility of returns, which offset their lower profitability and capitalisation. Some studies indicate that the lending pattern of cooperative banks is less procyclical than that of commercial banks, thereby smoothing the effects of the business cycles. Meriläinen (2016) for example, found that, although the 2008 crisis and the sovereign debt crisis hit the lending growth of banks in Western Europe, the shocks were partially absorbed by the cooperative and publicly owned savings banks, which maintained their lending growth.

Table 3.

Evidence of Cooperative Banking Stability versus Commercial Banks

\begin{tabular}{ll}
\hline More Stable & \multicolumn{1}{c}{ Less Stable } \\
\hline Hesse and Čihak (2007) & Barth et al. (2001) \\
Iannotta et al. (2007) & Goodhart (2004) \\
Beck et al. (2009) & Fonteyne (2007) \\
Chiaramonte et al. (2013) & Hesse and Čihák (2007) \\
Groeneveld (2014b) & \\
Ferri et al. (2014) & \\
Meriläinen (2016) & \\
Groeneveld (2017b) & \\
\hline
\end{tabular}


Given the synchronisation of theory and practice for cooperative banking and the incoherence within Islamic banking, we utilise the methodology to test whether, in mimicking conventional banks, Islamic banks have become less stable than their theoretical equivalent - cooperative banks.

\section{METHODOLOGY}

\subsection{Data}

\subsubsection{Sample selection}

The Islamic banks in this study are selected from five major countries, as defined by the IFSB Islamic financial services industry stability report 2016. The five countries are Malaysia, and four in the GCC, namely Saudi Arabia, Kuwait, the United Arab Emirates and Qatar ${ }^{1}$. This sample yields 37 Islamic banks (Table 4). The cooperative banks are from three European countries namely, Germany, Austria, and France. Given that this is the first study of its kind, a representative sample of banks is selected from European countries with diversified financial systems made up of commercial, cooperative and savings banks and a similar network of cooperative banks $^{2}$ (Table 5). This sample yields 1,536 banks.

Table 4.

Number of Islamic Banks in Study

\begin{tabular}{lc}
\hline & Islamic Banks \\
\hline Malaysia & 17 \\
Saudi Arabia & 4 \\
Kuwait & 5 \\
UAE & 7 \\
Qatar & 4 \\
Total & 37 \\
\hline
\end{tabular}

Table 5.

Number of Cooperative Banks in Study

\begin{tabular}{lc}
\hline & Cooperative Banks \\
\hline Germany & 1,001 \\
Austria & 452 \\
France & 83 \\
Total & 1,536 \\
\hline
\end{tabular}

We apply several criteria in the selection and treatment of banks. Firstly, given the existing problems in how some banks are classified in FitchConnect, we verified the classifications of Islamic and cooperative banks against the lists from each

1 The Islamic banking markets of these countries are considered systemically important because the assets are more than $15 \%$ of the total domestic banking assets.

2 Cooperative banks in Germany, Austria and France are considered to have a tighter integrated network than those of other countries such as Spain. 
country's central banks and their websites. The most significant issue with this new data source is that it includes several types of banks, including cooperative and savings banks under the label 'Retail \& Consumer Banks'. Therefore, they need to be filtered using either the central bank's classifications or the banks' websites and sometimes both.

Secondly, to ensure consistency, we only selected Islamic banks that are in the retail business of accepting deposits and disbursing loans, because this is the main business of cooperative banks in Europe. Other financial institutions, such as investment banks, private banks, asset management companies and non-deposittaking finance companies, are excluded. Thirdly, in line with Islamic banking stability studies and, in particular a study by Beck et al. (2013b), we mainly use unconsolidated data and supplement them with consolidated data when the former is not available to avoid doubling the subsidiaries.

Fourthly, we remove banks with less than three consecutive yearly observations because this is the minimum required by the GMM system. It is worth noting that $80 \%$ of the sample banks in Austria only have five of the nine-year observations due to a sourcing constraint. A representative from FitchConnect, the source of banking data for this study, explained that Austrian annual report data is typically difficult to locate. When a viable source is identified, only the last five-year data tend to be backfilled. Thus, most of the Raiffesenbanks (cooperatives) in Austria have data only from 2011, even though they have existed since the early 1900s. While this is not ideal, it must be accepted as one of the limitations of this research. In line with Beck et al. (2013a), we also winsorise the variables at the 1st and 99th percent levels to reduce the impact of outliers. Finally, while most of the bankspecific variables are in ratios, those in levels such as size are extracted in US dollars for consistency.

\subsubsection{Data Sources}

Given this study's focus on stability during the crisis and non-crisis years, annual banking data from FitchConnect, during the period 2007-2015, were collected. For the macroeconomic variables, data from the International Monetary Fund's (IMF) World Economic Outlook database and the IMF's International Financial Statistics were used. The governance variable is computed based on the World Bank's World Governance Indicator (Table 6).

\subsection{Model Development}

For the first time in stability studies, our model compares the stability of Islamic banks against cooperative banks while controlling for several potentially influential factors. This equation was used to compare their stability during a period of stress (GFC) and relative stability (2010-2015):

$$
\mathrm{Z}_{i, j, t}=\mathrm{c}+\beta_{0} \mathrm{Z}_{i, j, t-1}+\beta_{1} \mathrm{~B}_{i, j, t}+\beta_{2} \mathrm{I}_{j, t}+\beta_{3} \mathrm{M}_{j, t}+\beta_{4} \mathrm{IB}+\beta_{5} \mathrm{C}_{t}+\beta_{6} \mathrm{IBxC}_{t}+\beta_{7} \mathrm{SD}+\mu_{i t}
$$

where the dependent variable is the $Z$-score, $Z_{i, j, t}$ for bank $i$ in country $j$ at time $t$. The lagged variable, $Z_{i, j, t-1}$ is included to factor in the persistence of bank stability, 
possibly due to the capital reserves built over the previous periods (Chiaramonte et al., 2013; Liu et al., 2013). Controlling for the effects of extraneous factors, $B_{i . j t}$ is a vector of bank-specific variables, $\mathrm{I}_{j, t}$ are industry-specific variables, while $\mathrm{M}_{j, t}$ are macroeconomic variables (Abedifar et al., 2013; Chiaramonte et al., 2013; Hesse \& Čihák, 2007). The focus variables are in bold - the Islamic bank (IB) and crisis dummy $\left(C_{t}\right)$ and their interaction $\left(I B X C_{t}\right)$. The crisis years are defined as 2007-2009 and the non-crisis years are defined as 2010-2015. Another dummy, SD, is introduced to control the effects of the sovereign debt crisis in Europe. This dummv takes the value of 1 for the years 2010-2013 and 0 otherwise (Meriläinen, 2016). $\mu_{\text {it }}$ is the error term.

The dependent variable is a popular indicator of bank stability, the Z-score. It is popular because of its clear (inverse) relationship with the probability of a bank's insolvency. The formula is:

$$
\mathrm{Z}-\text { score }=\frac{\text { Roaa }+ \text { ETA }}{\sigma \text { Roaa }}
$$

where Roaa is the bank's return on average assets, ETA is the ratio of equity to total assets, and $\sigma$ Roaa is the standard deviation of the Roaa. The Z-score shows the number of standard deviations the returns would need to fall from the mean to wipe out the bank's equity. A higher Z-score, thus, indicates lower probability of insolvency and greater bank stability (Chiaramonte et al., 2013; Hesse \& Čihák, 2007). We use an accounting-based measure rather than a market-based one because most of the cooperative banks are not listed.

For the $\sigma$ Roaa, we compute the figure over the entire sample period in line with Demirgüç-Kunt et al. (2008), Laeven and Levine (2009), and Niu (2012), although other studies use a rolling three-year period. For the Z-score and its components, because they are highly skewed, we use the logarithms, which are normally distributed (Abedifar et al., 2013). Before taking the logarithm, we add five to all of the Z-scores because several Z-scores are negative and the logarithm of a negative number is undefined (Demirgüç-Kunt et al., 2008).

In line with related studies, the control variables include a number of bank-, industry-specific, and macroeconomic variables ${ }^{3}$. Since the size of banks can vary significantly, we use the logarithm of a bank's total assets in US dollars to control its effect on stability. The impact is uncertain. On the one hand, large banks benefit from diversification, economies of scale, and, in some cases, monopoly power (McAllister \& McManus, 1993). On the other hand, diversification can be harmful if they venture into risky products and business areas of which management has little knowledge.

For the wholesale funding risk (WFR), we use the ratio and deposits from banks to total assets as its control in line with Chiaramonte et al. (2013). Previously, deposits from customers were thought to be a risky source of funding given the withdrawal risk but the GFC has determined that banks that are dependent on

\footnotetext{
3 While other variables can arguably be included, the impact of omitted variables has been reduced through the use of dynamic panels.
} 
wholesale interbank markets are more exposed to the effects of crises (Bhattacharya \& Thakor, 1993; Butzbach \& von Mettenheim, 2015b). Since the numerator of the ratio consists of deposits, loans and repos from banks (including central banks), a higher WFR reflects a more interconnected banking system, thus, a potential domino effect during crises (López-Espinosa et al., 2012).

Other bank-related control variables include credit risk, cost efficiency and income diversity. Credit risk is proxied through the ratio of net loans to total assets, while that of cost efficiency is the cost-to-income ratio. Income diversity is included to control the effects of any deviation from an interest-based stability model. The proxy is, therefore, the ratio of non-interest income to gross revenue.

This study also includes industry-specific variables such as bank market concentration, market share of each type of bank, and governance. Bank market concentration, proxied by the Herfindahl-Hirschman index (HHI), is calculated based on the formula - a sum of squared market share of all banks - in terms of total assets in each country ${ }^{4}$.

In line with Čihák and Hesse (2010), the controls include a governance indicator, which is an average of six measures such as political stability, corruption control, and regulatory quality. The governance indicator is included to capture the differences in countries' institutional development, which may affect banking stability.

Alongside market concentration and governance, this study also includes a share of Islamic and cooperative banks as a control. As per Hesse and Čihák (2007) and Abedifar et al. (2013), market share is measured as the banks' total assets over the total banking sector assets in a country per year.

The third group of variables, macroeconomic, is made up of GDP, inflation, and exchange rate depreciation. The GDP measures the impact of an economy's total activity on banking stability while the latter two accounts for the impact of macroeconomic uncertainty. The full list of variables is exhibited in Table 6 .

A definition for the 2008 crisis warrants deliberation because it is among our key variables. In our study, we refer to its occurrence during the period 2007-2009; however, some researchers say 2008-2009 (Abedifar et al., 2013; Meriläinen, 2016). Official timelines, by the Federal Reserve Bank of St. Louis ('The Financial Crisis Full timeline,' n.d.) and the Bank for International Settlements (Filardo et al., 2010) identify the beginning of the crisis to be in the middle or third quarter of 2007. We set the start in 2007 because this study uses annual data and involves European countries (Fiordelisi \& Mare, 2014). The 2008-2009 definition is more appropriate for studies that do not involve advanced economies, because the crisis was initially confined to them. However, we also tested the results with the 2008-2009 dummy and the conclusions remained broadly unchanged.

\footnotetext{
${ }^{4}$ According to the US Department of Justice (DOJ), a value below 0.15 signals low concentration, while one above 0.25 suggests a high concentration. A moderately concentrated market is reflected in an index between 0.15 and 0.25 . These indications of HHI values are based on the DOJ's experience with firm mergers.
} 


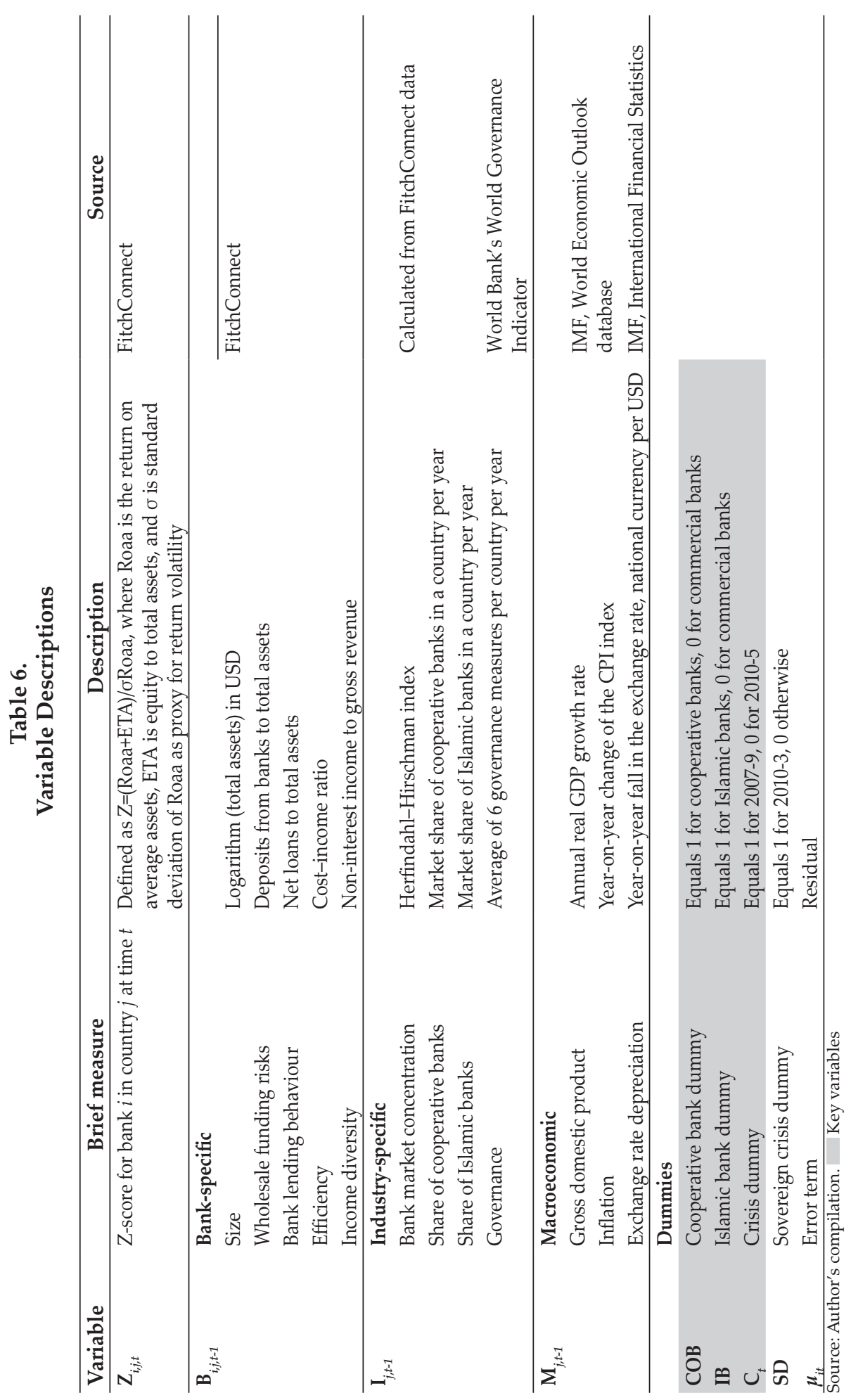


The non-crisis years are defined as 2010 to 2015; this is because official sources, such as the National Bureau of Economic Research - a think tank in the US that decides on the durations of economic downturns (Business Cycle Dating Committee, 2010) - declare the end of the crisis to be in 2009. The 'recovery' from 2010 onwards, however, was far from normal. These years were characterised by unusually lacklustre economic growth, tepid inflation, high unemployment, and stagnating wages (Blagrave \& Furceri, 2015). We, thus, consider them to be the 'new normal' of non-crisis years.

To ease interpretations, Table 7 provides interpretations of coefficients of the key variables, in line with the cautions discussed by Brambor et al. (2005) about interpreting interaction terms ${ }^{5}$. Regarding the research objective, if the coefficients of $\beta_{4}$ and $\beta_{6}(\mathrm{~A}-\mathrm{B})$ are jointly significant and negative, this means that Islamic banks were less stable than cooperative banks during the 2008 crisis. For the non-crisis period, the relevant coefficient for Islamic banks is $\beta_{4}$ (D-E). If it is significant and positive, this means that Islamic banks were more stable than cooperative banks during the non-crisis years (Ibrahim \& Rizvi, 2018). Although the two banks have different business models and aims, their heterogeneity is controlled through the selection of similarly retail-focused Islamic banks and the use of panel data.

Table 7.

Relevant Coefficients

\begin{tabular}{lccc}
\hline Coefficients & Crisis & Non-crisis & Crisis vs. Non-crisis \\
\hline Islamic banks (IB) & A: $\mathrm{c}+\beta_{4}+\beta_{5}+\beta_{6}$ & D: $\mathrm{c}+\beta_{4}$ & A-D: $\beta_{5}+\beta_{6}$ \\
Cooperative banks (COB) & B: $\mathrm{c}+\beta_{5}$ & E: $\mathrm{c}$ & B-E: $\beta_{5}$ \\
IB vs COB & A-B: $\beta_{4}+\beta_{6}$ & D-E: $\beta_{4}$ & \\
\hline
\end{tabular}

To verify the results, we performed robustness tests. We employed components of the Z-score, specifically their logarithms, as alternative dependent variables. Additionally, as an alternative measure of stability, the loan loss provisions as a percentage of gross loans was used (Abedifar et al., 2013; Ibrahim \& Rizvi, 2017). Finally, we regressed the Islamic banks against smaller samples of cooperative banks to bolster our findings.

\subsection{Method}

In terms of methodology, this study employed the two-step GMM system estimator with Windmeijer's (2005) corrected standard errors. The methodology, developed by Arellano and Bover (1995) and Blundell and Bond (1998), is particularly suitable for short and wide panels like ours. It also has other advantages. Firstly, the GMM system can produce consistent and efficient estimates despite endogeneity among

\footnotetext{
5 Brambor et al. (2005) specifically caution that interaction models should be used whenever the hypotheses are conditional in nature. Secondly, all constituent terms of the interaction variable should be included, except in certain rare circumstances. Thirdly, the constituent terms should not be interpreted on their own. Instead, scholars should calculate the substantively meaningful marginal effects and standard errors.
} 
the variables. This is relevant for our study because the lagged dependent variable - the Z-score - is consistently significant with coefficients greater than 0.8 in most of the regressions. Since the persistence means that current values of the Z-score are affected by past values, it should, thus, be included as an independent variable.

The inclusion of the lagged dependent variable can, however, cause endogeneity as it may be correlated with the error term, as do bank-related variables, which is a common problem in banking studies (Hossain, 2012). Static methods such as fixedand random-effect estimators tend to produce biased and inconsistent estimates in this situation. The GMM system overcomes the endogeneity issue by conducting the regressions in both differenced and levelled forms. For the regression in differences, the instruments are lagged levels of the variables while the regression in levels has instruments with lagged differences in the corresponding variables (Blundell \& Bond, 1998).

Secondly, with this technique, the list of control variables does not need to be exhaustive as the GMM system addresses the problem of omitted variable bias through the inclusion of individual-specific effects in the error term (Ibrahim \& Rizvi, 2017). Thirdly, the GMM system allows the inclusion of dummy variables, which would have been differenced in the first-difference GMM to partly resolve the endogeneity issue. Despite these advantages, the GMM system is only used in a handful of stability studies involving Islamic and cooperative banks. The technique is, thus, relevant for our study, which analyses whether Islamic banks have become less stable than their theoretical equivalent - cooperative banks.

To ensure the technique was working optimally, we performed three diagnostic tests suggested by Arellano and Bond (1991) and Arellano and Bover (1995) - the Hansen test for instrument validity, the autocorrelation test, and the number of instruments being below the sample size, or in our case, the number of banks.

\section{RESULTS AND ANALYSIS}

\subsection{Results}

\subsubsection{Descriptive Statistics}

Table 8 presents descriptive statistics of the logarithm's decomposition of the Z-scores $(\log Z)$ for Islamic and cooperative banks during the crisis and non-crisis periods. It is interesting that Islamic banks recorded consistently lower logZs during the two periods, indicating lower stability than that of cooperative banks. This seems to be primarily driven by a significantly higher volatility of returns (proxied through the standard deviation of Roaa), rather than a generally lower capitalisation or returns.

Table 8.

Decomposition of LogZ for Islamic and Cooperative Banks

\begin{tabular}{lcccccccc}
\hline & \multicolumn{2}{c}{ LogZ } & \multicolumn{2}{c}{ ETA \% } & \multicolumn{2}{c}{ Roaa \% } & \multicolumn{2}{c}{$\begin{array}{c}\text { Standard Deviation } \\
\text { of Roaa }\end{array}$} \\
\hline Banks & Crisis & Non & Crisis & Non & Crisis & Non & Crisis & Non \\
Islamic & 1.43 & 1.41 & 14.72 & 12.80 & 1.42 & 1.06 & 0.81 & 0.82 \\
Cooperative & 1.98 & 2.05 & 6.98 & 8.94 & 0.31 & 0.37 & 0.12 & 0.13 \\
\hline
\end{tabular}

Values shown are means. 
As shown in Figure 1, when these are juxtaposed, it is interesting to note that, in any given year between 2007 and 2015, Islamic banks consistently posted lower $\log Z$ s than cooperative banks. However, since such direct comparisons may not be fair - considering extraneous factors such as bank size, lending/financing behaviour, and each country's pace of growth, which may have had significant effects on banks' stability - we include them as controls in our regressions.

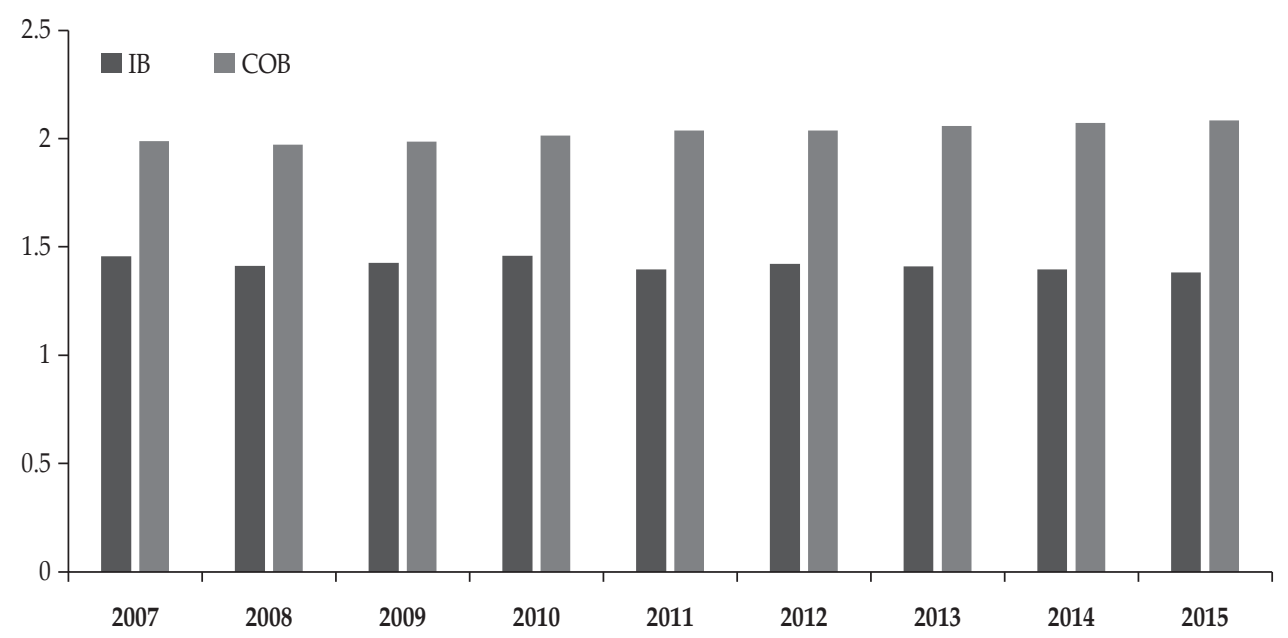

$\mathrm{IB}=$ Islamic banks; $\mathrm{COB}=$ Cooperative banks.

Figure 1.

LogZscore by Bank Type

There seem to be no major collinearity issues in our study; Table 9 shows the correlation coefficients between the variables in our equation. Most are below 0.60. Table 10 provides descriptive statistics for the control variables. 


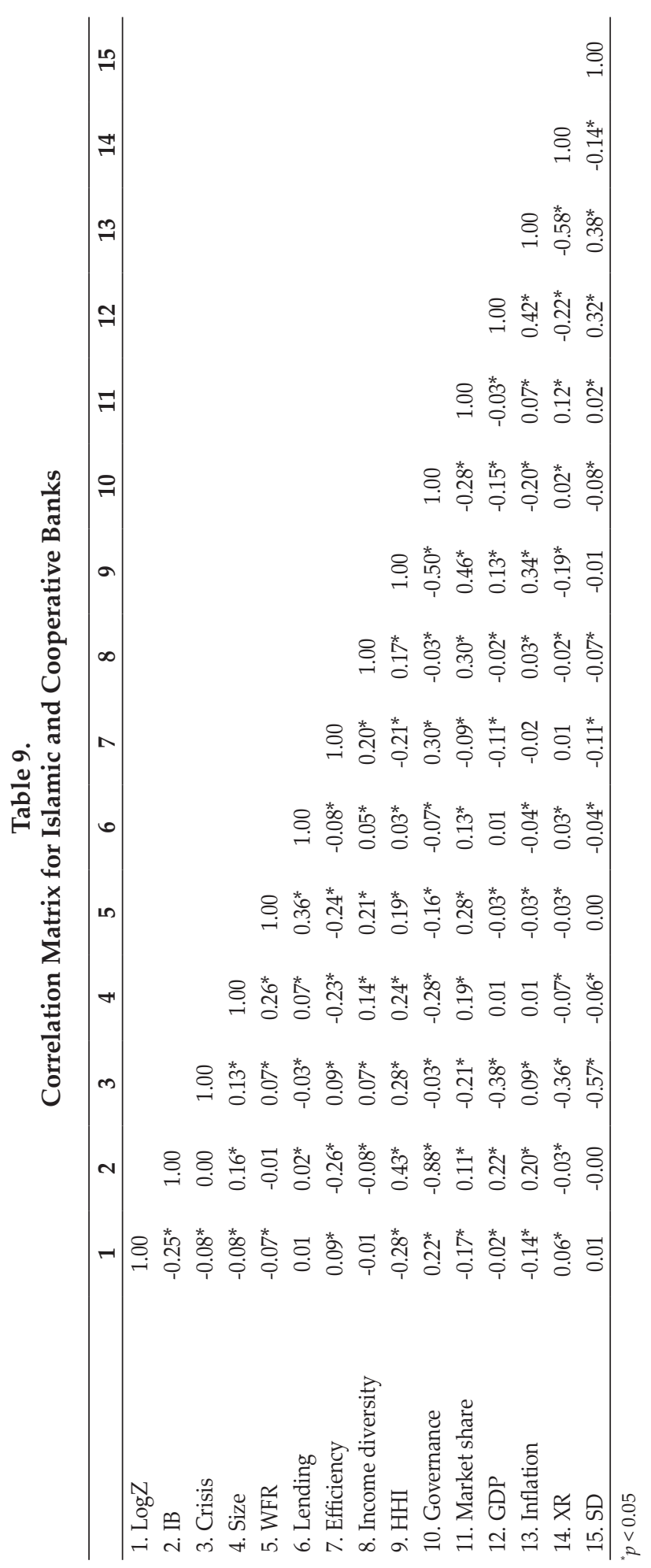


Table 10.

Control Variable Definition and Descriptions

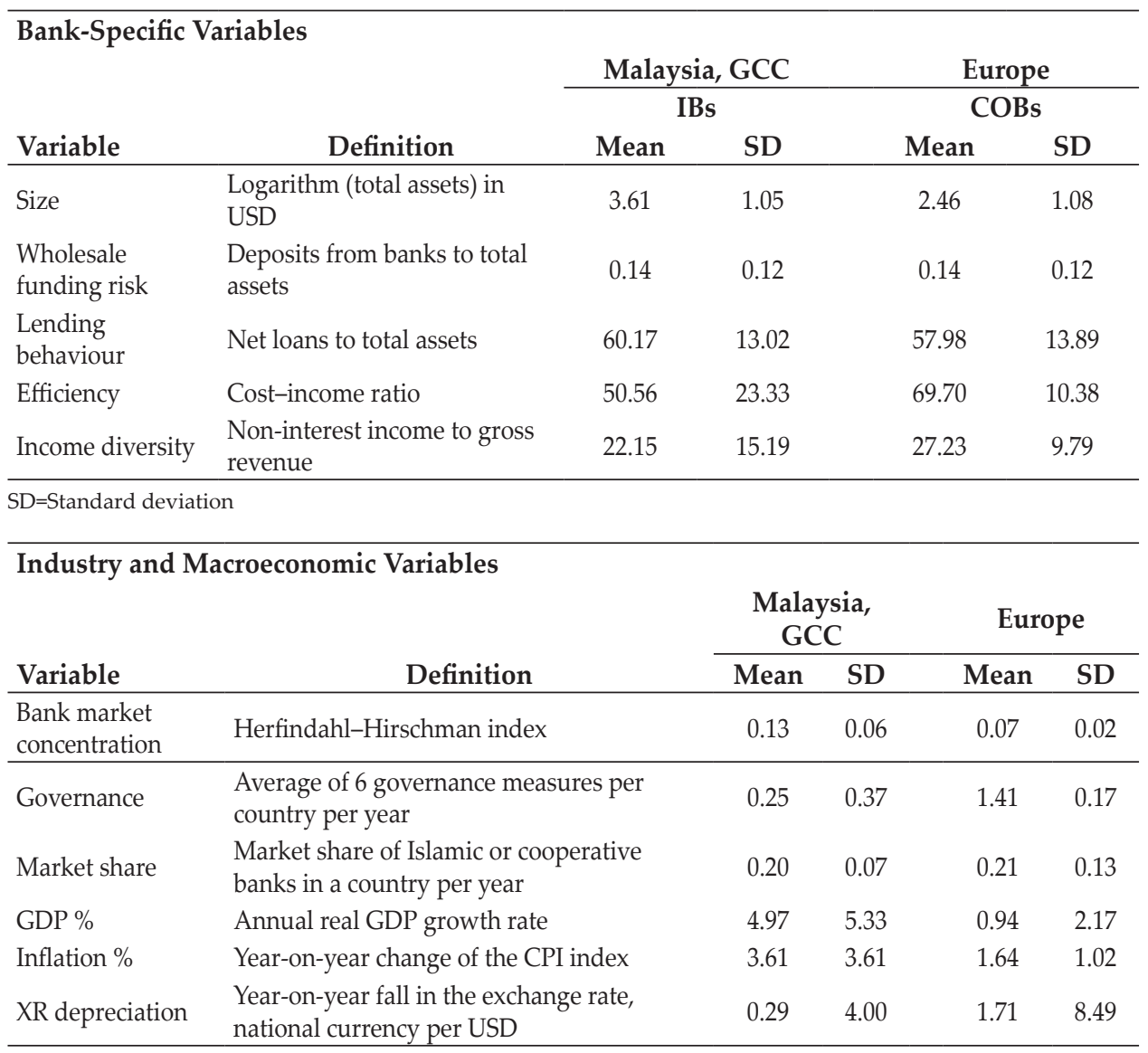

$\mathrm{SD}=$ Standard deviation

\subsection{Stability of Islamic versus Cooperative Banks}

Table 11 presents the estimation results for Islamic bank stability compared to those of cooperative banks in Europe. The key variables, as mentioned, are Islamic banks (IB) and crisis dummies (2007-2009 crisis) along with their interactions. In line with their interpretations as per Table 7 and Brambor et al. (2005), we provide the sum of the relevant coefficients and their $p$-values in parentheses. The $p$-values are derived from testing the null hypotheses and there is no significant difference in the stability of Islamic compared to that of cooperative banks during the crisis (i.e. $\beta_{4}+\beta_{6}=0$ ); there is also no significant difference in the stability of Islamic banks during the crisis compared to that of the non-crisis period (i.e. $\beta_{5}+\beta_{6}=0$ ). The standard errors of other variables are reported in square brackets. 


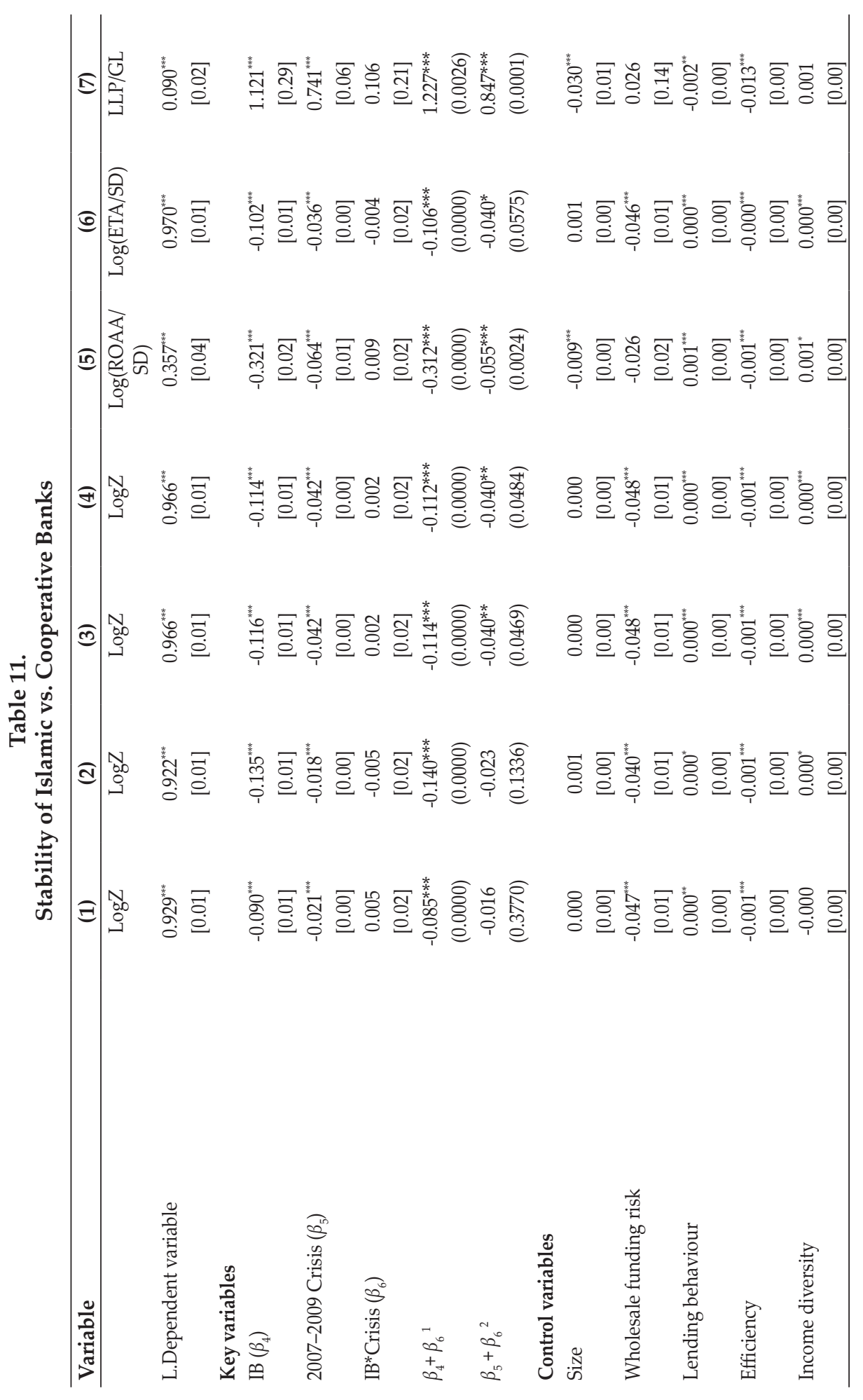




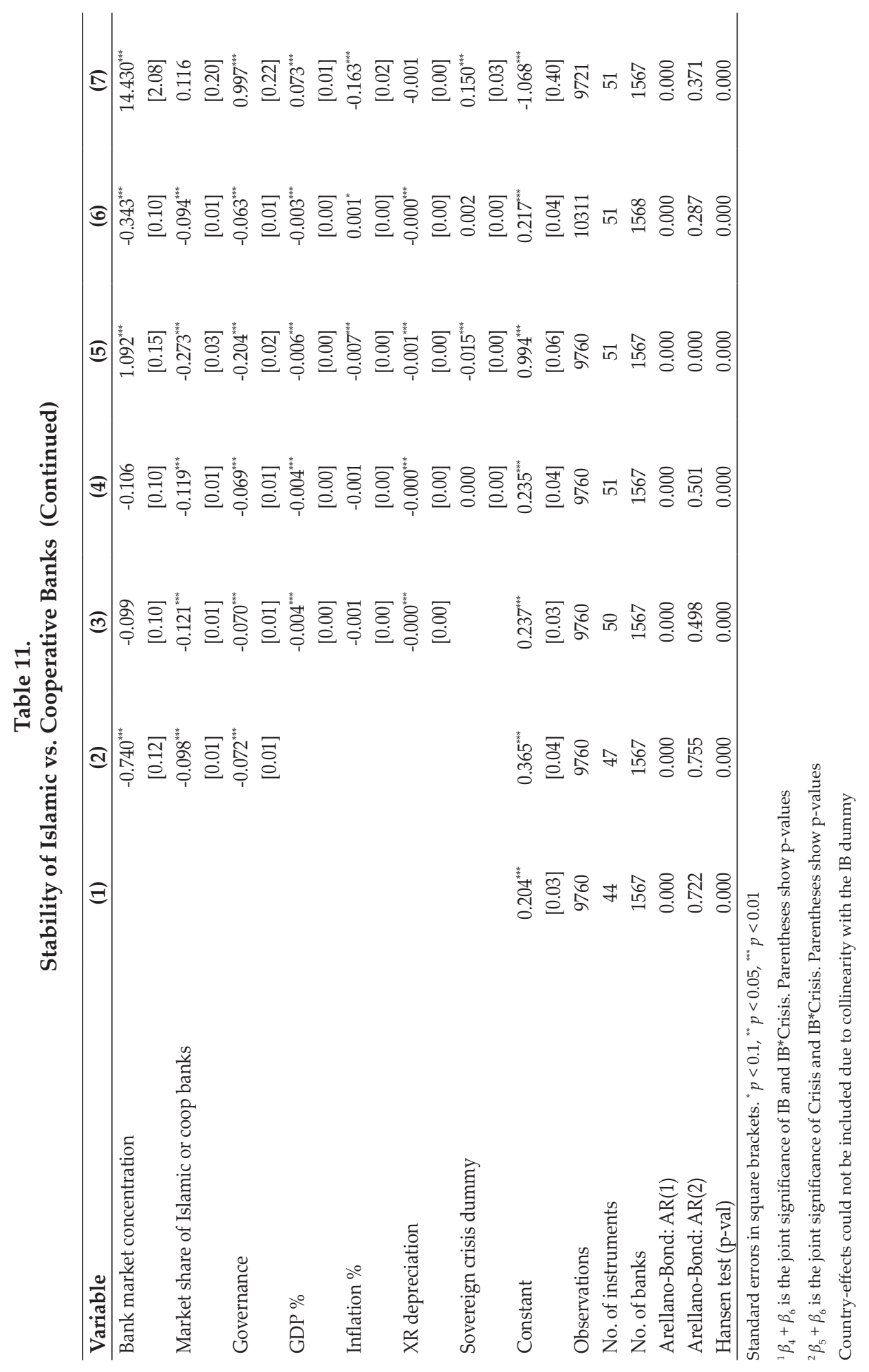


Table 11 includes the results for the control variables, which are under bank-, industry-specific and macroeconomic factor groups. Regressions (1) to (4) are based on the logarithm of the Z-score as the dependent variable with the groups of control variables progressively added. In addition, regressions (4) to (7) include the SD dummy, which controls for the effects of the sovereign debt crisis in Europe.

In terms of diagnostics, while the $\mathrm{AR}(2)$ tests and the number of instruments confirm the validity of our specifications, the null hypotheses of the Hansen test are rejected in all the regressions. This indicates that the instruments may be correlated with the error term, potentially affecting the estimates' consistency. We are not, however, overly concerned as several studies with similarly large numbers of observations have also encountered this issue (Araújo et al., 2011; Chiaramonte et al., 2013). The Hansen or Sargan test of overidentifying restrictions can show weaknesses in certain circumstances (Roodman, 2006). Specifically, in their Monte Carlo simulations, Blundell and Bond (2000, p. 329) note that there is 'some tendency for these test statistics (variations of the Sargan test) to reject a valid null hypothesis too often in these experiments and this tendency is greater at higher values of the autoregressive parameter'. As per Araújo et al. (2011) and Chiaramonte et al. (2013), we performed the Wald test, which confirms the validity of our model.

Interestingly, the result shows that Islamic banks were consistently and significantly less stable than cooperative banks in Europe during the GFC and non-crisis years. This is after considering the heterogeneity of the banks and their macroeconomic environments through techniques such as panel data and system GMM. The null hypotheses of $\beta_{4}+\beta_{6}=0$ are rejected in all regressions, as are the null of $\beta_{4}=0$. Their variables are consistently negative and significant at a $1 \%$ level. Notably, this finding is in line with Figure 1, which shows that, in any given year, Islamic banks record lower logZs than cooperative banks. In this regression, the conclusion is retained even after we make adjustments for explanatory factors, such as the effect of bank size, lending behaviour, and a country's growth pace on banking stability.

As for the comparative performance between the crisis and non-crisis years, both types of banks, unsurprisingly, showed lower stability during the crisis than during the non-crisis period. In most regressions, we reject the null hypothesis $\beta_{5}+\beta_{6}=0$ as well as $\beta_{5}=0$. The coefficients for Islamic banks $\left(\beta_{5}+\beta_{6}\right)$ and cooperative banks $\left(\beta_{5}\right)$ are negative in all regressions except (7), for which LLP/GL is the dependent variable. A far as the authors are aware, these findings are unprecedented, as there is no empirical comparison between Islamic and cooperative banks, despite their theoretical links.

Moving to the control variables, notably, the lagged dependent variable remained persistent, with coefficients greater than 0.8 and a $1 \%$ significance level. This confirms the effect of the past lags on the dependent variable in the equation and, thus, our choice of dynamic estimation model. Other variables record a number of robust relationships. Table 11 shows positive relationships between banking stability, lending behaviour and income diversity. However, robust, negative relationships at a $1 \%$ significance level are recorded between banking stability and wholesale funding risk, efficiency, market share of Islamic or cooperative banks, governance, GDP and the depreciation of exchange rates. 
In line with expectations, the sovereign crisis dummy shows adverse impacts on bank stability through profitability and loan loss provisions.

\subsection{Robustness Test}

Regressions (5) to (7) in Table 11 show the results of the robustness tests. The first two employ components of the Z-score, specifically their logarithms, as alternative dependent variables, while regression (7) uses an alternative measure of stability - loan loss provisions - as a percentage of gross loans. In addition, we regressed the stability of Islamic banks against smaller samples of cooperative banks in each European country (Table 12).

The results largely support our main finding that Islamic banks were consistently and significantly less stable than cooperative banks in Europe during the GFC and non-crisis years. The reason seems to lie in their lower profitability and capitalisation and the higher loan loss provisions that other factors controlled, in comparison to cooperative banks.

\section{Table 12}

Stability of IB vs. COB by country ${ }^{6}$

\begin{tabular}{lccc}
\hline Variable & Germany & Austria & France \\
\hline L.LogZ & $0.983^{* *+*}$ & $0.992^{* * * *}$ & $0.746^{* * *+}$ \\
& {$[0.02]$} & {$[0.02]$} & {$[0.09]$} \\
Key variables & & & \\
IB $\left(\beta_{4}\right)$ & $-0.081^{* * *}$ & -0.027 & $-0.188^{* *}$ \\
& {$[0.03]$} & {$[0.03]$} & {$[0.08]$} \\
2007-9 Crisis $\left(\beta_{5}\right)$ & $-0.037^{* * *}$ & $-0.014^{* *}$ & -0.001 \\
& {$[0.00]$} & {$[0.01]$} & {$[0.01]$} \\
IB*Crisis $\left(\beta_{6}\right)$ & -0.025 & 0.017 & -0.015 \\
& {$[0.02]$} & {$[0.02]$} & {$[0.02]$} \\
$\beta_{4}+\beta_{6}{ }^{1}$ & $-0.106^{* * *}$ & -0.01 & $-0.203^{* *}$ \\
& $(0.0031)$ & $0.7562)$ & $(0.0175)$ \\
Observations & 7583 & 1784 & 849 \\
No. of instruments & 50 & 50 & 50 \\
No. of groups & 1036 & 485 & 119 \\
Arellano-Bond: AR(1) & 0.000 & 0.000 & 0.000 \\
Arellano-Bond: AR(2) & 0.703 & 0.200 & 0.338 \\
Hansen test (p-val) & 0.000 & 0.008 & 0.001 \\
\hline
\end{tabular}

Standard errors in square brackets. ${ }^{*} p<0.1,{ }^{* *} p<0.05,{ }^{* * *} p<0.01$

${ }^{1} \beta_{4}+\beta_{6}$ is the joint significance of IB and IB*Crisis. Parentheses show $\mathrm{p}$-values

${ }^{2} \beta_{5}+\beta_{6}$ is the joint significance of Crisis and IB*Crisis. Parentheses show $\mathrm{p}$-values

6 The full set of results is available upon request 


\subsection{Analysis}

The findings indicate that Islamic banks are less stable than cooperative banks in Europe; this is the first empirical evidence that the dichotomy between theory and practice in Islamic banking is due to the misfit of a business model. It is also worth noting that the inferior stability of Islamic banks persisted at a $1 \%$ significance level during both the crisis and non-crisis periods. This is likely to indicate that the model misfit is constraining the potential of Islamic banks, regardless of the macroeconomic environment.

As mentioned earlier, this study is the first to explicitly state several paradoxes in Islamic banking, the main one of which is that the problem could be down to its adoption of the commercial banking model with debt as the main profit generator. At its core, current 'Islamic' banking is debt-churning through the 'two-tier murabahah' system. Profiting from debt is not only un-Islamic but is also destabilising. Debt, the engine of growth for commercial banks and the model looked up to by 'Islamic' banking governors and practitioners, has been blamed for the shortening cycles of booms and busts in the world today (Jha, 2013, 2014; Mian \& Sufi, 2015).

This study is among few that state that theoretically, the Islamic banking model is closer to the one used by cooperative banks. Regarding the arguments put forth by scholars such as Siddiqi (2006), Chapra (1985) and El-Gamal (2006a and 2006b) we further the discussion by being the first to draw parallels between Islamic banks and European cooperative banks. Specifically, our findings may help to close the gap between theory and practice in Islamic banking through the conclusion that a mutual-based model of cooperative banks is a better fit for the Shariah values that should be underpinning Islamic banking. In doing so, we have pointed to a potentially practical way of reforming 'Islamic' banks, which are accused of being 'Islamic' in all but name (Azmat et al., 2015; Khan, 2010; Foo, 2015).

In closing the gap between Islamic banking theory and practice, this study may have also solved the stability puzzle. While Islamic banks have, theoretically, been argued to be more stable than their conventional peers due to features such as mutuality and profit-sharing, the empirical evidence has been mixed. A significant number of studies have found that Islamic banks are more stable than their conventional counterparts but, of late, there is an increasing amount of research that has findings to the contrary. Some studies found no significant differences between Islamic and conventional banks, a likely testament to the formers' mimicking strategy. The issue, as mentioned, is that Islamic banks are being pushed for growth under the commercial banking model, which is an ill fit for the Shariah values that should be underpinning this form of banking. In pursuing the path of least resistance, 'Islamic' banking practitioners and governors may have unwittingly exacerbated the problem of instability, not to mention reputational damage, if a Shariah non-compliance risk is realised.

However, cooperative banking, in its embrace of Islamic-like virtues such as mutuality, customer before profits, prudence, moderation and sustainability, has fostered a long-term and risk-averse view in its stakeholders, which has led to stability. It did not escape the 2008 crisis unscathed. Larger cooperative banks, especially in Austria and France, suffered losses and had to accept state bail-outs; however, they were also among the earliest to return to profitability and settle 
their debts (Ayadi et al., 2010). This suggests the resilience of this banking model, which is not unlike the theoretical benefits that 'Islamic' banks should enjoy.

Although cooperative banks charge interest, which is undeniably against the Shariah, their founding objective has always been for the rates to be reasonable enough to allow financial access for those shunned by profit-driven commercial banks. Their concern for the community's wellbeing is underpinned by their mutual nature, which, as mentioned, aligns and, thus, reduces the conflicts of interest common to banking. This seems to have increased their stability while allowing them to contribute to the community. This stands in contrast to the 'contribution' of Islamic banks, which - although they purport Shariah values have hardly increased financial access within their communities (Naceur et al., 2015; El-Gamal, 2017); worse still, they have been found, in this study, to be less stable than their theoretical equivalent - cooperative banks.

This finding also indicates that comparison studies between Islamic and commercial banks may have missed the point; in practice, Islamic banks are far removed from their theoretical constructs, which are more congruous with a mutual form of banking. An appropriate comparison would, thus, be with cooperative banks in Europe.

Viewed as a whole, these results have significant policy implications, the most significant of which is to steer reform efforts away from the refurbishment of Islamic commercial banks and towards building an entirely new Islamic cooperative bank, based on the Europe model.

\section{CONCLUSION AND RECOMMENDATION}

\subsection{Conclusion}

In a crisis-charged world, financial stability has become important for central bankers. However, Islamic banking studies are plagued by several issues. Firstly, the comparison with commercial banks disregards the dichotomy between theory and practice. Theoretically, the interest prohibition should have pushed Islamic banks towards mutuality and profit-sharing, which are argued to be stabilising. In practice, however, banks are pushed for growth under a debt-driven commercial banking model, which is not only antithetical to the Shariah values that should underpin Islamic banking, but is also destabilising. This paradox seems to have led to the second issue of divergent empirical findings in Islamic banking stability studies. For the first time, this study seeks to determine whether, in mimicking conventional banks, Islamic banks have become less stable than their theoretical equivalent - cooperative banks in Europe. Interestingly, we found empirical evidence for the hypothesis during both the 2008 crisis and the non-crisis years.

\subsection{Recommendation}

The main policy implication of this study is the realisation for 'Islamic' banking governors, practitioners and academics that what the reform efforts need to achieve is not a modified 'Islamic' bank based on a commercial banking model, but an entirely new Islamic cooperative bank, based on the European model, particularly that of Germany. Given its in-built inclinations towards the Shariah, it would be 
much easier to produce a bank that conforms to Islamic values; this would mean a genuine refrain from interest and debt, while conforming to the current legal and financial frameworks, although some modifications would, undoubtedly, still be necessary.

\section{REFERENCES}

Abedifar, P., Molyneux, P., \& Tarazi, A. (2013). Risk in Islamic banking. Review of Finance, 17(6): 2035-2096.

Abedifar, P., Giudici, P., \& Hashem, S. Q. (2017). Heterogeneous Market Structure and Systemic Risk: Evidence from Dual Banking Systems. Journal of Financial Stability, 33, 96-119.

Alandejani, M., Kutan, A. M., \& Samargandi, N. (2017). Do Islamic Banks Fail more than Conventional Banks? Journal of International Financial Markets, Institutions and Money, 50, 135-155.

Allen, F. \& Gale, D. (1997). Financial Markets, Intermediaries, and Intertemporal Smoothing. Journal of Political Economy, 105(3), 523-546.

Al-Muharrami, S. M., \& Hardy, D. (2013). Cooperative and Islamic Banks: What can they learn from each other? International Monetary Fund .

Alqahtani, F., Mayes, D. G., \& Brown, K. (2017). Reprint of Economic Turmoil and Islamic Banking: Evidence from the Gulf Cooperation Council. Pacific-Basin Finance Journal, 42, 113-125.

Altunbas, Y., Evans, L., \& Molyneux, P. (2001). Bank Ownership and Efficiency. Journal of Money, Credit and Banking, 926-954.

Araújo, B. C., Bogliacino, F., \& Vivarelli, M. (2011). Technology, Trade and Skills in Brazil: Evidence from Micro Data. CEPAL Review, (105).

Arellano, M. \& Bond, S. (1991). Some Tests of Specification for Panel Data: Monte Carlo evidence and An Application to Employment Equations. The Review of Economic Studies, 58(2): 277-297.

Arellano, M. \& Bover, O. (1995). Another Look at The Instrumental Variable Estimation of Error-Components Models. Journal of Econometrics, 68(1): 29-51.

Ariff, M. (2014). Whither Islamic Banking? The World Economy, 37(6): 733-746.

Ashraf, D., Ramady, M., \& Albinali, K. (2016). Financial Fragility of Banks, Ownership Structure and Income Diversification: Empirical Evidence from the GCC region. Research in International Business and Finance, 38, 56-68.

Ayadi, R., Llewellyn, D. T., Schmidt, R. H., Arbak, E., \& Pieter De Groen, W. (2010). Investigating Diversity in the Banking Sector in Europe: Key Developments, Performance and Role of Cooperative Banks. Centre for European Policy Studies.

Azmat, S., Skully, M., \& Brown, K. (2015). Can Islamic Banking ever become Islamic? Pacific-Basin Finance Journal, 34, 253-272.

Baltagi, B. (2005). Econometric Analysis of Panel Data. John Wiley \& Sons.

Bank for International Settlements. (2010). Basel III: A Global Regulatory Framework for more Resilient Banks and Banking Systems [PDF file]. Retrieved from https:// www.bis.org/publ/bcbs189.pdf

Barth, J. R., Caprio Jr, G., \& Levine, R. (2001). Supervision: What works and what doesn't, Banking Systems around the Globe: Do Regulation and Ownership Affect Performance and Stability? (pp. 31-96). University of Chicago Press. 
Bashir, A., Darrat, A. F., \& Suliman, M. O. (1993). Equity Capital, Profit Sharing Contracts, and Investment: Theory and Evidence. Journal of Business Finance $\mathcal{E}$ Accounting, 20(5): 639-651.

Beck, T., H. Hesse, T. Kick and N. von Westernhagen (2009). Bank Ownership and Stability: Evidence from Germany. [Online article]. Retrieved from http:// voxeu.org/article/bank-ownership-and-stability-evidence-germany

Beck, T., De Jonghe, O., \& Schepens, G. (2013a). Bank Competition and Stability: Cross-Country Heterogeneity. Journal of Financial Intermediation, 22(2): 218-244.

Beck, T., Demirgüç-Kunt, A., \& Merrouche, O. (2013b). Islamic vs. Conventional Banking: Business Model, Efficiency, and Stability. Journal of Banking E Finance, 37(2): 433-447.

Bhattacharya, S., \& Thakor, A. V. (1993). Contemporary Banking Theory. Journal of financial Intermediation, 3(1): 2-50.

Blagrave, P. \& Furceri, D. (2015). Lower Potential Growth: A New Reality. IMF Survey Magazine, April 7.

Blundell, R. \& Bond, S. (1998). Initial Conditions and Moment Restrictions in Dynamic Panel Data Models. Journal of Econometrics, 87(1), 115-143.

Blundell, R., \& Bond, S. (2000). GMM Estimation with Persistent Panel Data: An Application to Production Functions. Econometric Reviews, 19(3), 321-340.

Bourkhis, K. \& Nabi, M. S. (2013). Islamic and Conventional Banks' Soundness during the 2007-2008 Financial Crisis. Review of Financial Economics, 22(2), 6877.

Brambor, T., Clark, W. R., \& Golder, M. (2005). Understanding Interaction Models: Improving Empirical Analyses. Political Analysis, 14(1), 63-82.

Business Cycle Dating Committee, National Bureau of Economic Research. (September 20, 2010). Retrieved from http://www.nber.org/cycles/sept2010. html

Butzbach, O. \& von Mettenheim, K. (2015a). Alternative Banking and Financial Crisis, Introduction (pp. 1-9). Pickering \& Chatto (Publishers).

Butzbach, O \& von Mettenheim, K. (2015b). Alternative Banking and Financial Crisis, Explaining the Competitive Advantage of Alternative Banks: Towards an Alternative Banking Theory? (pp. 51-69). Pickering \& Chatto (Publishers).

Chapra, M. U. (1985). Towards a just Monetary System (Vol. 8). International Institute of Islamic Thought (IIIT).

Chiaramonte, L., Poli, F., \& Oriani, M. E. (2013). Are Cooperative Banks a Lever for Promoting Bank Stability? Evidence from the recent Financial Crisis in OECD countries. European Financial Management, 21(3), 491-523.

Chong, B. S., \& Liu, M. H. (2009). Islamic Banking: Interest-free or Interest based? Pacific-Basin Finance Journal, 17(1), 125-144.

Čihák, M. \& Hesse, H. (2010). Islamic Banks and Financial Stability: An Empirical Analysis. Journal of Financial Services Research, 38(2-3), 95-113.

Darrat, A. F. (1988). The Islamic Interest-free Banking System: Some Empirical Evidence. Applied Economics, 20(3), 417-425.

Demirgüç-Kunt, A., Detragiache, E., \& Tressel, T. (2008). Banking on the Principles: Compliance with Basel Core Principles and Bank Soundness. Journal of Financial Intermediation, 17(4), 511-542. 
El-Gamal, M.A. (2006a). A SimpleFiqh-And-Economics Rationale for Mutualization in Islamic Financial Intermediation. Houston: The Rice University. Retrieved December 25, 2017.

El-Gamal, M. A. (2006b). Islamic Finance: Law, Economics, and Practice. Cambridge University Press.

El-Gamal, M. A. (2017). "Islamic Finance" After State-Sponsored Capitalist Islamism. Rice University's Baker Institute for Public Policy. Retrieved from https:// www.bakerinstitute.org/research/islamic-finance-after-state-sponsoredcapitalistislamism/

Farooq, M., Zaheer, S. (2015). Are Islamic Banks more Resilient during Financial Panics? Pacific Economic Review, 20(1), 101-124.

Ferri, G., Kalmi, P., \& Kerola, E. (2014). Does Bank Ownership Affect Lending Behavior? Evidence from the Euro area. Journal of Banking $\mathcal{E}$ Finance, 48, 194209.

Filardo, A. et al. (2010). The International Financial Crisis: Timeline, Impact and Policy Responses in Asia and the Pacific. BIS Papers, 52, 21-82.

Fiordelisi, F. \& Mare, D. S. (2014). Competition and Financial Stability in European Cooperative Banks. Journal of International Money and Finance, 45, 1-16.

Fonteyne, M. W. (2007). Cooperative Banks in Europe: Policy Issues (No. 7-159). International Monetary Fund.

Foo, Y. N. Special Report: The Shariah Debate on Islamic Financing (October 30, 2015), The Edge Financial Daily. Retrieved from http://www.theedgemarkets. com/article/special-report-shariah-debate-islamic-financing

Ghatak, M. (2000). Screening by the Company you keep: Joint Liability Lending and the Peer Selection Effect. The Economic Journal, 110(465), 601-631.

Goglio, S. \& Y. Alexopoulus (2014, Eds.), Special Issue on Cooperative Banks, Journal of Entrepreneurial and Organisational Diversity, 3(1), Trento, Italy.

Goodhart, C. A. E. (2004). Some New Directions for Financial Stability? (Vol. 27). Bank for International Settlements.

Groeneveld, H. M. (2014a). Features, Facts and Figures of European Cooperative Banking Groups Over Recent Business Cycles. Journal of Entrepreneurial and Organizational Diversity, Special Issue on Cooperative Banks, 3(1), 11-33.

Groeneveld, H. (2014b). Alternative Banking and Financial Crisis, A Qualitative and Statistical Analysis of European Cooperative Banking Groups (pp. 71-100). Pickering \& Chatto (Publishers).

Groeneveld, H.M. (2017b). European Co-operative Banks in 2016: A Concise Assessment. Retrieved from http://www.eacb.coop/en/studies/externalstudies/european-co-operative-banks-in-2016-a-concise-assessment-tiasschool-for-business-amp-society.html

Gulzar, R. (2016) “German Banks: More Islamic than Islamic Banks?" NUS-MEI Islamic Finance Special.

Hegazy, W. S. (2006). Contemporary Islamic Finance: From Socioeconomic Idealism to Pure Legalism. Chicago Journal of International Law, 7, 581.

Hesse, H., \& Čihák, M. (2007). Cooperative Banks and Financial Stability. International Monetary Fund.

Hossain, M. (2012). Financial Reforms and Persistently High Bank Interest Spreads in Bangladesh: Pitfalls in Institutional Development? Journal of Asian Economics, 23(4), 395-408. 
Hussain, H.A. \& Al-Ajmi, J. (2012). Risk Management Practices of Conventional and Islamic Banks in Bahrain. The Journal of Risk Finance, 13(3), 215-239.

Iannotta, G., Nocera, G., \& Sironi, A. (2007). Ownership Structure, Risk and Performance in The European Banking Industry. Journal of Banking $\mathcal{E}$ Finance, 31(7), 2127-2149.

Ibrahim, M. H. (2016). Business Cycle and Bank Lending Procyclicality in A Dual Banking System. Economic Modelling, 55, 127-134.

Ibrahim, M. H. \& Rizvi, S. A. R. (2017). Do We Need Bigger Islamic Banks? An Assessment of Bank Stability. Journal of Multinational Financial Management, 40, 77-91.

Ibrahim, M. H. \& Rizvi, S. A. R. (2018). Bank Lending, Deposits and Risk-Taking in Times of Crisis: A Panel Analysis of Islamic and Conventional Banks. Emerging Markets Review.

IFSB. (2016). Islamic Financial Services Industry Stability Report.

Jha, Y. (2013). From Goldsmiths to Modern Banking: A Frank Look at MoneyCreation Process and Its Relevance to Islamic Banking. Islam and Civilisational Renewal (ICR), 4(3).

Jha, Y. (2014). The Destructive Logic of Interest: The Fallacy of Perpetual Growth (With a Discussion of Reformist Action by Islamic Bank). Islam and Civilisational Renewal (ICR), 5(3).

Kabir, M. N., Worthington, A., \& Gupta, R. (2015). Comparative Credit Risk in Islamic and Conventional Bank. Pacific-Basin Finance Journal, 34, 327-353.

Kalmi, P. (2007). The Disappearance of Cooperatives from Economics Textbooks. Cambridge Journal of Economics, 31(4), 625-647.

Kay, J. (2016). Other People's Money: Masters of the universe or Servants of the people? Profile Books Limited.

Khan, F. (2010). How "Islamic" is Islamic Banking? Journal of Economic Behavior and Organization, 76, 805-820.

Kuran, T. (1995). Islamic Economics and the Islamic Subeconomy. The Journal of Economic Perspectives, 9(4), 155-173.

Laeven, L. \& Levine, R. (2009). Bank Governance, Regulation and Risk taking. Journal of Financial Economics, 93(2), 259-275.

Liu, H., Molyneux, P., \& Wilson, J. O. (2013). Competition and Stability in European Banking: A Regional Analysis. The Manchester School, 81(2), 176-201.

López-Espinosa, G., Moreno, A., Rubia, A., \& Valderrama, L. (2012). Short-term Wholesale Funding and Systemic Risk: A Global CoVaR Approach. Journal of Banking \& Finance, 36(12), 3150-3162.

Mansour, W., Ben Jedidia, K., \& Majdoub, J. (2015). How Ethical is Islamic Banking in the Light of the Objectives of Islamic Law? Journal of Religious Ethics, 43(1), $51-77$.

McAllister, P. H. \& McManus, D. (1993). Resolving the Scale Efficiency Puzzle in Banking. Journal of Banking \& Finance, 17(2-3), 389-405.

Meriläinen, J. M. (2016). Lending Growth during the Financial Crisis and the Sovereign Debt Crisis: The Role of Bank Ownership Type. Journal of International Financial Markets, Institutions and Money, 41, 168-182.

Mian, A. \& Sufi, A. (2015). House of debt: How they (and you) caused the Great Recession, and how we can prevent it from happening again. University of Chicago Press. 
Mobarek, A. \& Kalonov, A. (2014). Comparative Performance Analysis between Conventional and Islamic Banks: Empirical Evidence from OIC countries. Applied Economics, 46(3), 253-270.

Naceur, M. S. B., Barajas, M. A., \& Massara, M. A. (2015). Can Islamic Banking Increase Financial Inclusion? (No. 15-31). International Monetary Fund.

Niu, J. (2012). An Empirical Analysis of the Relation between Bank Charter Value and Risk taking. The Quarterly Review of Economics and Finance, 52(3), 298-304.

Pappas, V., Ongena, S., Izzeldin, M., \& Fuertes, A. M. (2017). A Survival Analysis of Islamic and Conventional Banks. Journal of Financial Services Research, 51(2), 221-256.

Roodman, D. (2006). How to do Xtabond 2: An Introduction to Difference and System GMM in Stata. Center for Global Development.

Siddiqi, M. N. (1983a). Banking without Interest (Vol. 5). Islamic Foundation.

Siddiqi, M. N. (1985). Partnership and Profit-Sharing in Islamic Law (Vol. 9). Islamic Foundation.

Siddiqi, M. N. (2006). Islamic Banking and Finance in Theory and Practice: A Survey of State of the Art. Islamic Economic Studies, 13(2), 1-48.

Solomon, D. (November 20, 2014). The Recovery from the Global Financial Crisis of 2008: Missing in Action. [Blog post]. Retrieved from https://blog.euromonitor. com/2014/11/the-recovery-from-the-global-financial-crisis-of-2008-missing-inaction.html

Sorwar, G., Pappas, V., Pereira, J., \& Nurullah, M. (2016). To Debt or Not To Debt: Are Islamic Banks Less Risky than Conventional Banks? Journal of Economic Behavior E Organization, 132, 113-126.

The Financial Crisis - Full timeline. (n.d.). Retrieved from https://www.stlouisfed. org/financial-crisis/full-timeline\#2010

Valnek, T. (1999). The Comparative Performance of Mutual Building Societies and Stock Retail Banks. Journal of Banking E Finance, 23(6), 925-938.

Windmeijer, F. (2005). A Finite Sample Correction for the Variance of Linear Efficient Two-Step GMM Estimators. Journal of Econometrics, 126(1), 25-51. 